\title{
Relationship between environmental parameters and the plankton community of the Batuhideung Fishing Grounds, Pandeglang, Banten, Indonesia
}

\author{
NOVERITA D. TAKARINA", WAWAN NURLIANSYAH"^, WISNU WARDHANA \\ ${ }^{1}$ Department of Biology, ${ }^{2}$ Graduate Program in Marine Science, Faculty of Mathematics and Natural Sciences, Universitas Indonesia. \\ Jl. Lingkar UI, Depok 16424, West Java, Indonesia."email: veri641@gmail.com, "vwawannurlians@gmail.com
}

Manuscript received: 1 December 2017. Revision accepted: 14 December 2018.

\begin{abstract}
Takarina ND, Nurliansyah W, Wardhana W. 2019. Relationship between environmental parameters and the plankton community of the Batuhideung Fishing Grounds, Pandeglang, Banten, Indonesia. Biodiversitas 20: 171-180. Phytoplankton has a role as primary producers and zooplankton as primary consumers in the marine environments. The composition of the plankton community is dependent on the physical and chemical characteristics of the waters. The aim of the research described here was to analyze the community structure of plankton in the Batuhideung Fishing Grounds, of Banten in Indonesia, and to relate this structure to the physical parameters (sea surface temperature, clarity, current velocity) and chemical parameters (salinity, $\mathrm{pH}, \mathrm{DO}$, nitrate, phosphate) of its sea surroundings. The research was conducted three times at five observation stations from September to October 2017. Samples of phytoplankton and zooplankton were taken horizontally using nets with mesh size of $80 \mu \mathrm{m}$ and $133 \mu \mathrm{m}$, respectively. Results showed that the sea surface temperature ranged from $28.70-30.20^{\circ} \mathrm{C}$, current velocity $0.10-1.30 \mathrm{~m} / \mathrm{s}$, clarity $7-10 \mathrm{~m}$, salinity $30-34 \mathrm{~g} / \mathrm{L}, \mathrm{DO} 6.20-$ $8.60 \mathrm{mg} / \mathrm{L}, \mathrm{pH} 8.40-8.59$, nitrate concentration $0.49-0.81 \mathrm{mg} / \mathrm{L}$, and phosphate concentration $0.09-0.42 \mathrm{mg} / \mathrm{L}$. There were 37 genera from 4 classes of phytoplankton. The abundance of Bacillariophyta was 52,734 individuals/L, Myzozoa was 1,315 ind/L, Chyanophyta was $633 \mathrm{ind} / \mathrm{L}$, and Euglenophyta was $200 \mathrm{ind} / \mathrm{L}$. There were 35 genera from 12 classes of zooplankton, dominated by Copepods with abundance $82.1-91.4 \%$. The diversity index of phytoplankton ranged from 1.25-2.02, evenness index ranged from $0.52-0.85$, and dominance index ranged from 0.19-0.38. Based on multivariate cluster analysis, there were similar environmental parameters in stations 1, 2 and 3, while stations 4 and 5 grouped differently from the other three. Based on Pearson's correlation analysis, current velocity and phosphate were positively correlated to phytoplankton abundance, whereas temperature, transparency, salinity, DO, $\mathrm{pH}$, and nitrate were negatively correlated, temperature significantly so. Nitrate, phosphate, salinity, DO were positively correlated with zooplankton abundance but not significantly. Temperature, current velocity, clarity, and $\mathrm{pH}$ were negatively correlated with zooplankton abundance, but only with $\mathrm{pH}$ did the correlation reach statistical significance.
\end{abstract}

Keywords: Batuhideung water, environmental parameters, phytoplankton, zooplankton

\section{INTRODUCTION}

The waters of Pandeglang District, Banten, Indonesia belong to the fishery management area (WPP) 572 which covers the Indian Ocean, west of Sumatra and the Sunda Strait (Fauziyah et al. 2018; Sutiana et al. 2018). These waters in the area of the Sunda Strait and the Java Sea and are a component of the circulating water masses of Indonesia. The dynamics of the water body are influenced by the flow of two major water masses, the Java Sea water mass in the north and the Indian Ocean water mass in the south (Amri et al. 2014). Mixing the two water masses has a positive impact on the quality of the Sunda Strait water mass; it affects the content of seston, suspended solids, phytoplankton, chlorophyll, and nutrients. The waters of the Sunda Strait are very dynamic and influenced by the current system in the Java Sea and Indian Ocean (Ke et al. 2014; Xu et al. 2018). Local phenomena such as seasons and volcanic activity in the Sunda Strait affect oceanographic characteristics, so that the Pandeglang waters have significant potential as fishing grounds.

The water quality parameters of the sea environment are influenced by biological, chemical and physical factors. Seawater temperature data provides information not only about the physical state of the ocean, but also closely influence the life of marine organisms, both plants, and animals (Yao and Somero 2014). Sea temperature is a factor influencing the processes of photosynthesis and metabolism of marine biota (Mc Connaughey and Zottoli 1983; Longhurst and Pauly 1987). Fertility of the waters is determined by its nutrient content. Biologically, the plankton community structure plays an important role in determining the biotic richness of the marine environment. Parameters of community structure include abundance, diversity, uniformity and plankton dominance.

Plankton is microscopic organisms; water currents strongly influence their movement in the sea. Phytoplankton is important primary producers in the food chain of the marine ecosystems, fundamental to the fate of other organisms higher in the food chain (Vajravelu et al. 2018). Plankton can be an indicator of water fertility, and their abundance and diversity are positively correlated with the potential productivity of a fishing area (Kasma et al. 2007; Hemraj et al. 2017). 
The study reported in this paper aimed to analyze the relationship between the sea's environmental parameters (temperature, clarity, current velocity, salinity, $\mathrm{pH}, \mathrm{DO}$, nitrate, and phosphate) and the structure of the sea's plankton community structure.

\section{MATERIALS AND METHODS}

\section{Study area}

This research was conducted from September to October 2017. Sampling was conducted in the Batuhideung fishing area, coordinates, $06^{\circ} 28^{\prime} \mathrm{S}$ and $105^{\circ} 33 \mathrm{~N}$, in Pandeglang, Banten Province, Indonesia as shown in Figure 1. Purposive sampling was used to select the locations of the five observation stations. Observation and measurement of water quality parameters was carried out in situ (Abdul et al. 2016).

\section{Procedures}

Plankton was sampled horizontally with a constant vessel velocity of maximum 2-5 knots using $80 \mu \mathrm{m}$ and $133 \mu \mathrm{m}$ plankton net size. The plankton samples were inserted in $250 \mathrm{~mL}$ sample bottles, and preserved with $4 \%$ formalin (Abdul et al. 2016). Plankton samples were identified and analyzed for its abundance in the Laboratory of Fish and Environmental Examination (LP2IL) at Serang, Banteng, Indonesia, using the Sedgwick-Rafter Counting Cell method. Measurements of nitrate and phosphate parameters were performed using Van Dorn Bottles; water samples were inserted in $250 \mathrm{~mL}$ volume sample bottles for analysis in the LP2IL Laboratory at Serang.

\section{Data analysis}

Analysis and calculation (counting) of plankton abundance was conducted using the sub-sampling method which used 1 cell per 1 liter for phytoplankton and 1 individual per 1 liter for zooplankton respectively (APHA 1979).

$$
\mathrm{N}=\frac{l}{p} \times q \times \frac{1}{v}
$$

Where:

$\mathrm{N}=$ anbundance (cell/L)

$1=$ number of sample/plankter in sub-sample

$\mathrm{p}=$ volume of sub-sample

$1=$ volume of sample

$\mathrm{v}=$ volume of filtered water

Diversity index was calculated using the ShanonWiener index (Odum 1971), as below.

$$
H^{\prime}=\sum_{t=1}^{s} P i \cdot \ln P i
$$

Where:

$\mathrm{H}^{\prime}=$ Diversity index

$\mathrm{Pi}=\mathrm{ni} / \mathrm{N}$

$\mathrm{ni}=$ number of individuals from genus $\mathrm{i}$

$\mathrm{N}=$ total number of individuals

$\mathrm{s}=$ number of genus
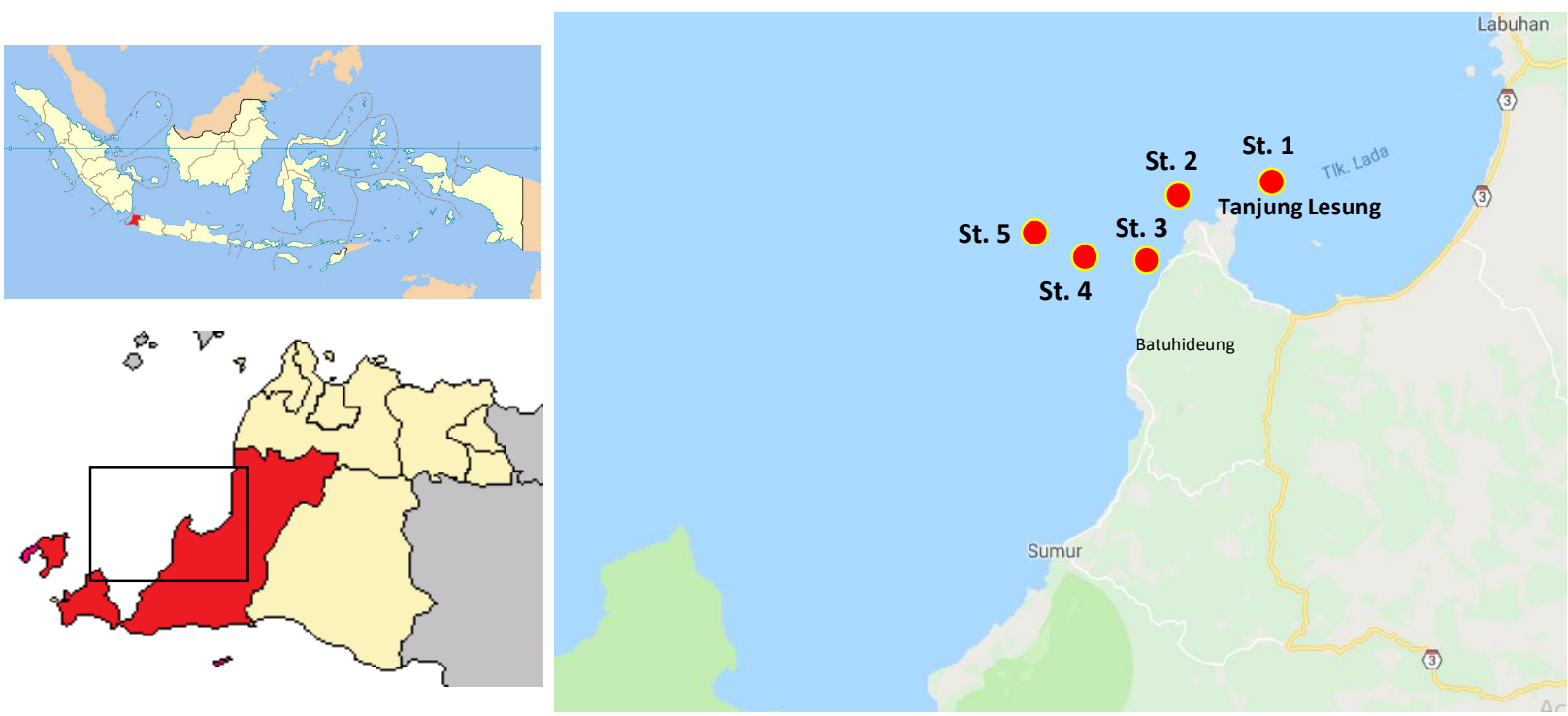

Figure 1. Sampling location in Batuhideung waters, Pandeglang, Banten, Indonesia 
Evenness index describes the value of similarity of the number of individuals between genera in a community. This index can be used as a dominance indicator for certain plankton genera. This index was calculated using formula as below (Odum 1971).

$$
E=\frac{H^{\prime}}{H \max }
$$

Where:

$\mathrm{E}=$ evenness index $(0-1)$

$\mathrm{H}^{\prime}=$ diversity index

$\mathrm{Hmax}=$ maximum diversity index $=\ln \mathrm{S}$

$\mathrm{S}=$ number of taxon

Dominance index was calculated using Simpson dominance index (Odum 1971; Krebs 1989).

$$
C=\sum\left(\frac{}{N}\right)^{2}
$$

Where:

$\mathrm{C}=$ Dominance index

$\mathrm{ni}=$ number of individuals from genus $\mathrm{i}$

$\mathrm{N}=$ number of total individuals

The distribution of water quality parameters (Temperature, Clarity, Current velocity, Salinity, $\mathrm{pH}, \mathrm{DO}$, Nitrate Phosphate) was analyzed and mapped using software Surfer 12. The relationship between water quality and plankton community structure (plankton abundance) was analyzed using Minitab version 18.

\section{RESULTS AND DISCUSSION}

\section{Environmental parameters \\ Temperature}

September-October 2017, the period of study, was a transitional season with stable temperatures; the temperature ranged from $28.7-30.2^{\circ} \mathrm{C}$ with an average value of $29.52^{\circ} \mathrm{C}$ (Figure 2). This was in accordance with Renaud et al. (2002), which records that phytoplankton can tolerate water temperatures in the range $20-30^{\circ} \mathrm{C}$.

\section{Clarity}

Based on Figure 3, clarity ranged between 7-10 m with the average value of $8.5 \mathrm{~m}$. According to Brierley (2017), light is one of the limiting factors for primary productivity of plankton.

\section{Current velocity}

Current velocity in Batuhideung waters from September to October 2017 ranged from 0.1 to 1.3 meters/second with an average value of 0.34 meters/second. Current is very important in the distribution of plankton especially phytoplankton, because the swimming capability is very limited and the plankton is always transported by the sea currents (Hays 2017). The current distribution during the period of observation can be seen in Figure 4.

\section{Salinity}

The distribution of salinity in Batuhideung waters during the period of observation from September to
October 2017 ranged from 30-34 \%. In the third week of observation (October 1, 2017) the distribution of salinity values at each observation station was unvarying, i.e. $30 \%$. The salinity value remained within a good range for plankton growth. The optimal salinity of plankton is between 20-35 \% (Isnansetyo and Kurniastuty 1995). The distribution of salinity can be seen in Figure 5.

\section{Acidity degree ( $p H)$}

The $\mathrm{pH}$ values of Batuhideung waters from September to October 2017 did not vary greatly, ranging from 8.40 to 8.59 with an average value of 8.5. The $\mathrm{pH}$ values were tolerable for biota growth especially plankton, as waters with $\mathrm{pH}$ values varying between 7-8 can be tolerated by most aquatic biota (Nybakken 1992). Distribution of $\mathrm{pH}$ values during the period of observations can be seen in Figure 6.

\section{Dissolved oxygen (DO)}

The distribution of dissolved oxygen (DO) values in Batuhideung waters during observation from September to October 2017 ranged from 6.2 to $8.6 \mathrm{mg} / \mathrm{L}$, with an average value of $8.5 \mathrm{mg} / \mathrm{L}$ (Figure 7). The fertile waters of Batuhideung waters would promote the life of more phytoplankton than the concentrations of dissolved oxygen could support. It is about $50 \%$ of the photosynthesis process on the earth's surface is contributed by marine phytoplankton (Basu and Mackey 2018).

\section{Nitrate}

Nitrate concentration during observation in SeptemberOctober 2017 in Batuhideung waters ranged from 0.49 to $0.81 \mathrm{mg} / \mathrm{L}$, with an average value of $0.6316 \mathrm{mg} / \mathrm{L}$. The highest nitrate concentration of $0.81 \mathrm{mg} / \mathrm{L}$ occurred on the first occasion of observation in week 1 (September 3, 2017) and the lowest nitrate concentration of $0.49 \mathrm{mg} / \mathrm{L}$ occurred on the second occasion observation, on September 17, 2017. Based on the Decree of the Minister of Environment No. 51 of 2004, the quality standard for nitrate concentration in seawater is $<0.008 \mathrm{mg} / \mathrm{L}$. This means that nitrate content in the Batuhideung waters in the period of observation was high. The nutrient input from the mainland, from human activities and from fishing activities in Batuhideung waters was the probable cause of the high nitrate levels. Nitrate is a major metabolic input in the growth of phytoplankton and the high observed nitrate levels had the potential to stimulate high phytoplankton growth (Cira et al. 2016). The distribution of nitrate concentrations during the period of observation can be seen in Figure 8.

\section{Phosphate}

Phosphate concentrations ranged from 0.10 to 0.42 $\mathrm{mg} / \mathrm{L}$, with an average value of $0.16 \mathrm{mg} / \mathrm{L}$ (Figure 9). This concentration in the waters exceeded the seawater phosphate quality standard of $0.015 \mathrm{mg} / \mathrm{L}$ defined by the Decree of the Minister of Environment no. 51 year 2014. The main function of phosphate for marine biota, especially for plankton, is as an input into the energy generating metabolic processes (Lin et al. 2016). 
Sea surface temp. profile of $1^{\text {st }}$ week (September 3, 2017)

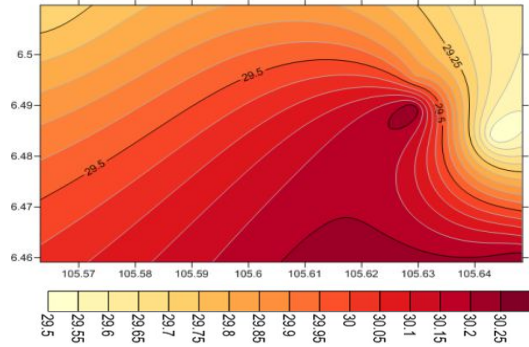

Sea surface temp. profile of $2^{\text {nd }}$ week (September 17, 2017)

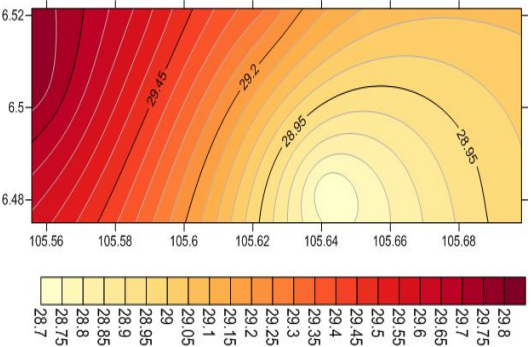

Sea surface temp. profile of $3^{\text {rd }}$ week (October 1, 2017)

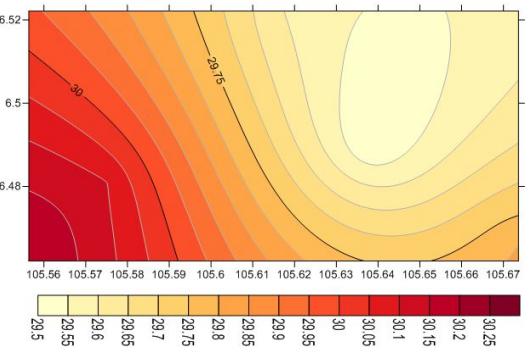

Figure 2. Distribution in Batuhideung waters of sea surface temperature in relation to longitude from 3rd September to 1st October 2017

Brightness profile of $1^{\text {st }}$ week (September 3, 2017)

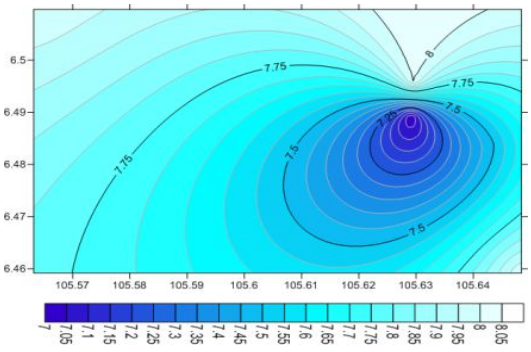

Brightness profile of $2^{\text {nd }}$ week (September 17, 2017)

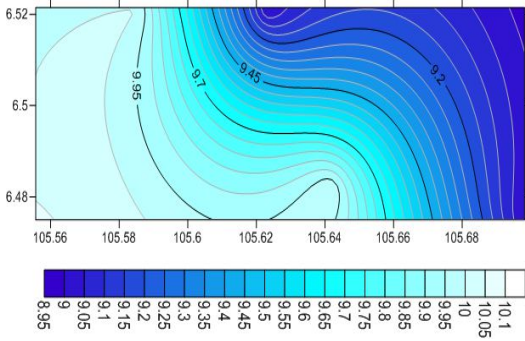

Brightness profile of $3^{\text {rd }}$ week (October 1, 2017)

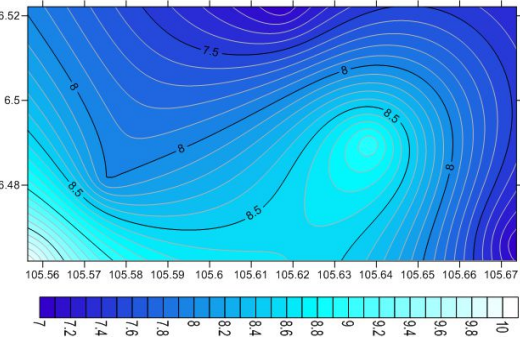

Figure 3. Distribution in Batuhideung waters of water clarity in relation to longitude from 3rd September to 1st October 2017

Current velocity profile of $1^{\text {st }}$ week (September 3, 2017)

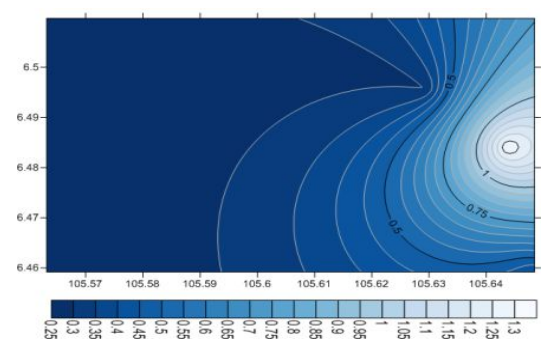

Current velocity profile of $2^{\text {nd }}$ week (September 17,2017 )

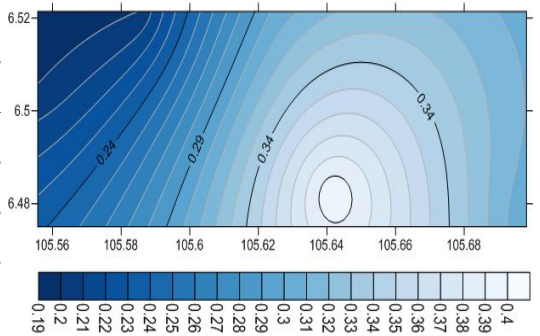

Current velocity profile of 3 rd week (October 1,2017)

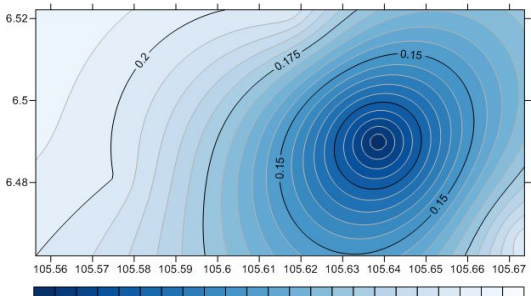

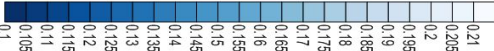

Figure 4. Distribution in Batuhideung waters of sea current velocity in relation to longitude from 3rd September to 1st October 2017

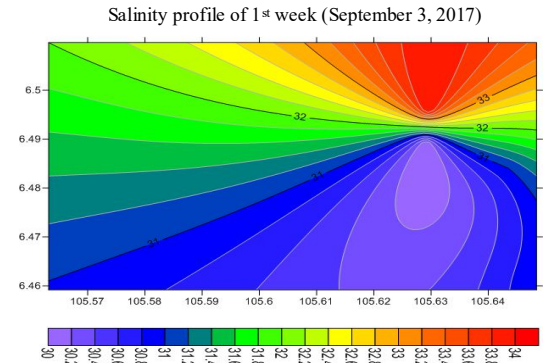

Salinity profile of $2^{\text {nd }}$ week (September 17, 2017)

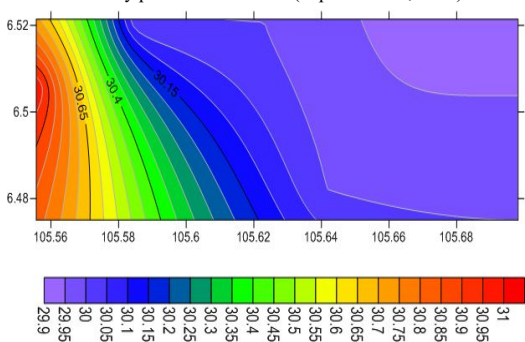

Figure 5. Distribution in Batuhideung waters of salinity in relation to longitude on 3rd and 17th September 2017 

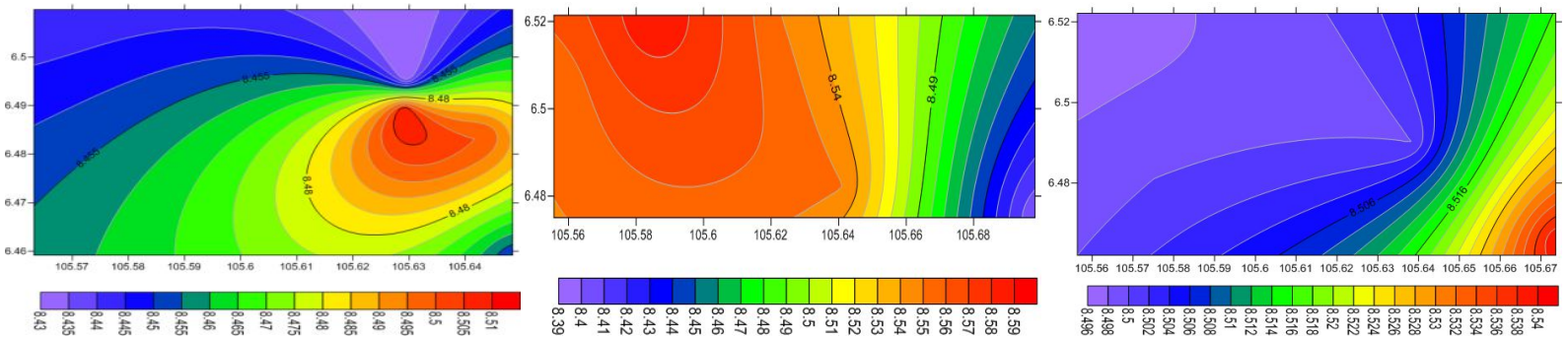

Figure 6. Distribution in Batuhideung waters of $\mathrm{pH}$ in relation to longitude from 3rd September to 1st October 2017

Dissolved oxygen profile of $1^{\text {st }}$ week (September 3, 2017)

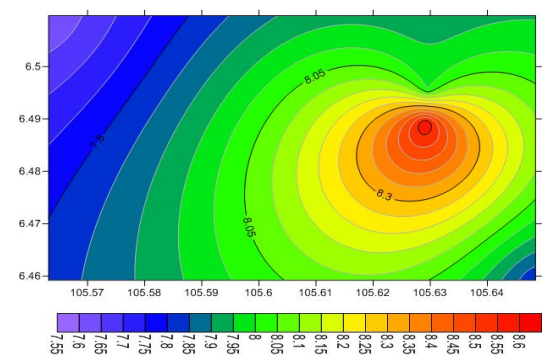

Dissolved oxygen profile of $2^{\text {nd }}$ week (September 17, 2017)

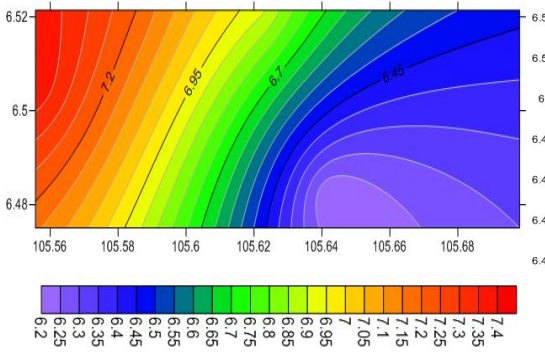

Dissolved oxygen profile of $3^{\text {rd }}$ week (October 1, 2017)

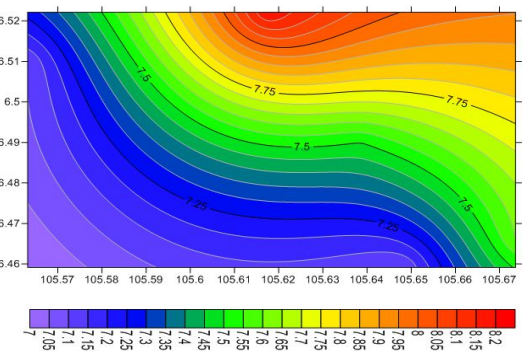

Figure 7. Distribution in Batuhideung waters of Dissolved Oxygen(DO) in relation to longitude from 3rd September to 1st October 2017

Nitrite conc. distr. profile of $1^{\text {st }}$ week (September 3, 2017)

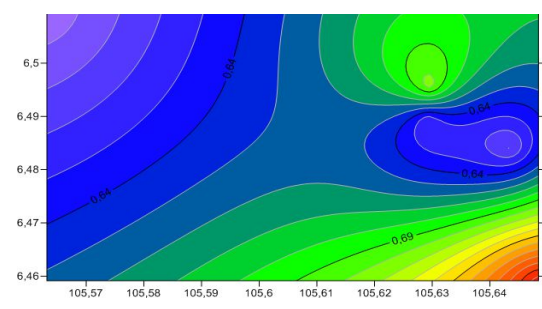

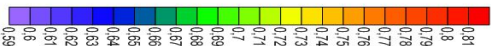

Nitrite conc. distr. profile of $2^{\text {nd }}$ week (September 17, 2017)
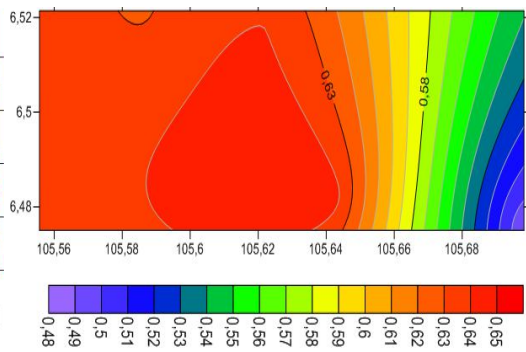

Nitrite conc. distr. profile of $3^{\text {rd }}$ week (October 1, 2017)

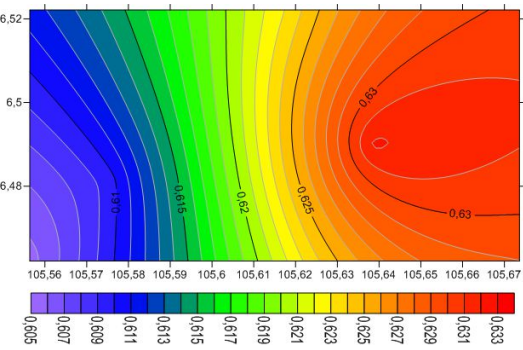

Figure 8. Distribution in Batuhideung waters of nitrate in relation to longitude from 3rd September to 1st October

Phosphate conc. distr. profile of $1^{\text {st }}$ week (September 3, 2017)

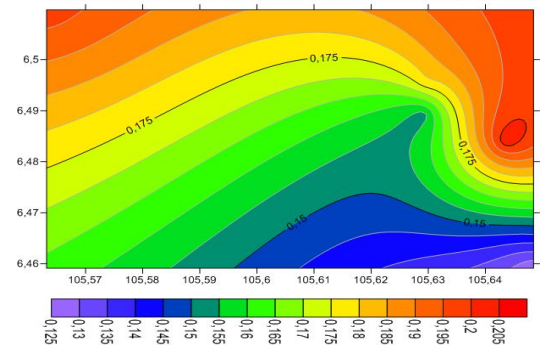

Phosphate conc. distr. profile of $2^{\text {nd }}$ week (September 17, 2017)

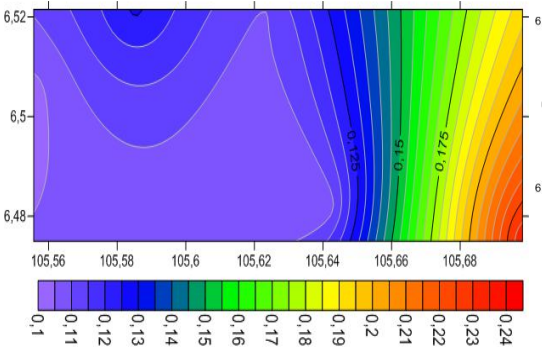

Phosphate conc. distr. profile of $3^{\text {rd }}$ week (October 1, 2017)

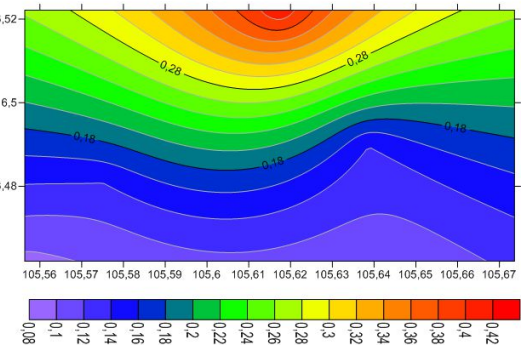

Figure 9. Distribution in Batuhideung waters of phosphate in relation to longitude from 3rd September to 1st October 


\section{Phytoplankton}

Based on observation and identification of plankton, phytoplankton consisted of 37 genera from 4 phyla namely Bacillariophyta (28 genera), Myzozoa (6 genera), Chyanophyta (3 genera) and Euglenophyta (1 genus) as shown in Table 1. The total abundance of phytoplankton in Batuhideung waters in September-October 2017 ranged from $2,785-, 29,425$ individuals/L across the observation stations.

Table 2 shows that the greatest abundance was observed at Station $1(29,425 \mathrm{ind} / \mathrm{L})$ while the least abundance $(2,785 \mathrm{ind} / \mathrm{L})$ was observed in Station 5. This difference in abundance was possible because of difference in the water quality between those stations. The distribution of phytoplankton across the stations was uneven and was undoubtedly influenced by variation in physical and chemical factors in the waters such as temperature, current velocity, clarity, salinity, $\mathrm{pH}, \mathrm{DO}$ and nutrient content (Cui et al. 2018; Bharathi et al. 2018). In particular, the likely cause of the high abundance of phytoplankton at station 1 was the high nutrient concentration of inputs from the land, due to human activity.

Table 1 and 2 show that Bacillariophyte and Dinophyte (Phylum Myzozoa) were the most abundant; 52,734 ind/L and 1,315 ind/L, respectively. Phytoplankton from the Bacillariophyte and Dinophyte classes are generally the most common producers in trophic waters (Odum 1971, Madhu et al. 2017). This was also in accordance with Simon et al. (2009) who reported that the Bacillariophyceae are the most abundant class of phytoplankton found in the marine environment, because they are able to adapt to its aquatic environment, have a good tolerance, and have high resistance to environmental change.

Table 1. The abundance of phytoplankton (ind/L) in Batuhideung waters, Pandeglang, Banten, Indonesia

\begin{tabular}{|c|c|c|c|c|c|c|}
\hline \multirow{2}{*}{ Phylum } & \multirow{2}{*}{ Genus } & \multicolumn{5}{|c|}{ Station } \\
\hline & & St.1 & St.2 & St.3 & St.4 & St.5 \\
\hline \multirow[t]{27}{*}{ Bacillariophyta } & Bacteriastrum & 80 & - & 20 & 5 & - \\
\hline & Biddulphia & 730 & 30 & 220 & - & - \\
\hline & Cerataulina & 440 & 47 & 215 & 33 & 35 \\
\hline & Chaetoceros & 9,040 & 1,170 & 2,640 & 1,158 & 955 \\
\hline & Coscinodiscus & 75 & 57 & 70 & 35 & 40 \\
\hline & Ditylum & 65 & 40 & 90 & 10 & 15 \\
\hline & Eucampia & 20 & - & - & - & - \\
\hline & Guinardia & 1,760 & 87 & 660 & 38 & 55 \\
\hline & Gyrosigma & 20 & 27 & 75 & - & - \\
\hline & Hemiaulus & 380 & 67 & 230 & 80 & 60 \\
\hline & Hemidiscus & 200 & 213 & 425 & 35 & 15 \\
\hline & Leptocylindrus & - & 17 & 195 & - & - \\
\hline & Licmophora & - & 10 & - & - & - \\
\hline & Navicula & 170 & 65 & 185 & - & - \\
\hline & Nitzschia longissima & 5 & 5 & - & - & - \\
\hline & Nitzschia paradoxa & - & 17 & 25 & - & - \\
\hline & Nitzschia & 220 & 50 & - & - & - \\
\hline & Pleurosigma & 140 & 67 & 10 & - & - \\
\hline & Pseudo-nitzschia & 7,815 & 1,893 & 2,470 & 125 & 65 \\
\hline & Rhizosolenia & 6,855 & 1,785 & 4,095 & 1,858 & 1,150 \\
\hline & Skeletonema & 10 & 83 & - & 20 & 55 \\
\hline & Surirella & 10 & - & - & - & - \\
\hline & Synedra & 5 & - & - & - & - \\
\hline & Thallasionema & - & 17 & 10 & 10 & - \\
\hline & Thallasiosira & 80 & - & 50 & - & 5 \\
\hline & Thallasiotrix & 250 & 245 & 340 & 190 & 170 \\
\hline & Triceratium & 120 & - & 10 & - & - \\
\hline \multirow[t]{3}{*}{ Chyanophyta } & Oscillatoria & - & 13 & 70 & 5 & - \\
\hline & Trichodesmium & - & 80 & - & 430 & 10 \\
\hline & Anabaena & - & - & 25 & - & - \\
\hline Euglenophyta & Euglena & 200 & - & - & - & - \\
\hline \multirow[t]{6}{*}{ Myzozoa } & Alexandrium & 120 & - & - & - & - \\
\hline & Ceratium & 205 & 92 & 60 & 98 & 125 \\
\hline & Dinophysis & - & 5 & 45 & - & 25 \\
\hline & Gymnodinium & 180 & 10 & 30 & 5 & 5 \\
\hline & Noctiluca & 210 & 20 & 60 & - & - \\
\hline & Protoperidinium & 20 & - & - & - & - \\
\hline Total & & 29,425 & 6,212 & 12,325 & 4,135 & 2,785 \\
\hline
\end{tabular}


Values for Diversity, Evenness and Simpson indices in the distribution of phytoplankton at each of the five stations are presented in Table 3. The values for the phytoplankton diversity index across the stations ranged from 1.25 to 2.02 . This implied that the biota community in Batuhideung waters was moderately stable. The evenness index ranged from $0.52-0.85$. A value for evenness of 1.0 would have indicated an unvarying proportion in the number of individuals in the distribution of phytoplankton. The Simpson index values ranged from $0.19-0.38$. A value of 0.0 for the Simpson index would have indicated that no species dominate in the Batuhideung waters.

\section{Zooplankton}

Zooplankton composition consisted of 35 genera from 12 phyla; namely Arthropoda (12 genus), Mollusca (5 genus), Chaetognatha (1 genus), Crustacea (2 genera), Chordata (3 genera), Actinopoda (2 genera), Annelida (3 genus), Ciliophora (2 genera), Nematodes (1 genus), Cnidaria (1 genus), Protozoa (1 genus) and Rotifera (1 genus). The abundance of phytoplankton in Batuhideung waters in September-October 2017 ranged from 279-480 ind/L across the observation stations (Table 4 ).

The data presented in Figure 10 show that the Arthropod phylum was the dominant group at each station with an abundance of $82.1-91.4 \%$. This is in accordance with the report of Nybakken (1992), and Pratiwi et al. (2016) and Yang et al. (2017), recording that the largest portion of the zooplankton was of the Arthropod phylum; almost all of them belonging to the copepod subclass of the Crustacea (Acartia sp., Centropages sp., Oithona sp., Sapphirina sp.). Copepoda is small-sized holoplanktonic crustacea that dominate the zooplankton of all seas and oceans. Copepoda is primary herbivores in the ocean and acts as a very important link between the primary production of the phytoplankton and carnivores small and large (Tan and Rangsangan 2017). In addition to the dominant copepods, there are also members of the Cladocera suborder (Podon sp.) which are small holoplankton animals filtering smaller animals or phytoplankton from the sea (Giesecke et al. 2017).

Values for Diversity, Evenness and Simpson indices in the distribution of zooplankton at each of the five stations are presented in Table 5. The values for the zooplankton diversity index across the stations ranged from 0.96 to 1.91 . This implied that the stability of the zooplankton community in Batuhideung waters was generally moderate. However, at stations 3 and 4 the index value of diversity dropped to less than $1(\leq 1)$ on some observational occasions, implying some degree of instability in the biota community. The values for the Evenness indices for zooplankton ranged from 0.54-0.87. A value for evenness of 1.0 would have indicated an unvarying proportion in the number of individuals in the distribution of zooplankton. The Simpson index ranged from 0.19-0.54. A value of 0.0 for the Simpson index would have indicated that no species dominate in the Batuhideung waters.

\section{Clustering stations based on water quality}

The degree of similarity between the five observation stations in physical and chemical water qualities was determined by multivariate cluster analysis. The clusters based on analysis of the parameters of the marine environment at the five sites is presented in Figure 11. The clustering separated into two groups: group 1 (stations 1,2 and 3 ) and group 2 (stations 4 and 5). This is in accordance with locations for the stations; group 1 sites were in coastal water 500-1000 meters from the mainland, while the group 2 sites were in waters about 4000-5000 meters from the mainland.

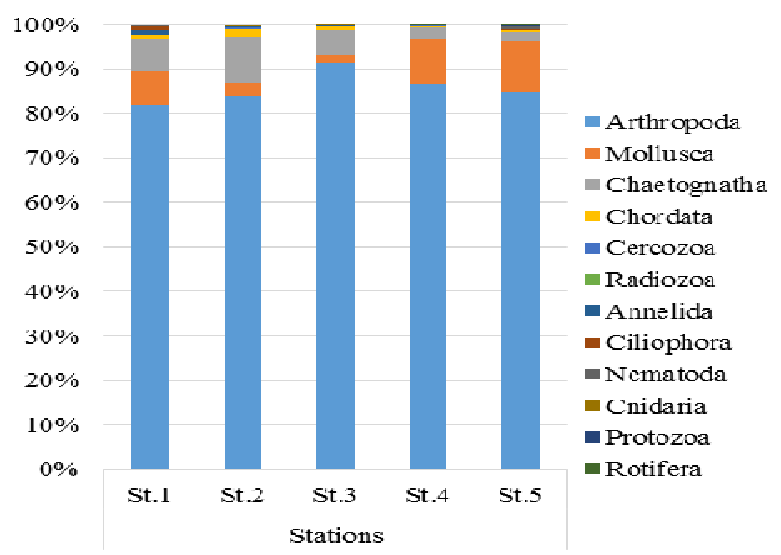

Figure 10. Zooplankton abundance from each genus in Batuhideung waters, Pandeglang, Banten, Indonesia (SeptemberOctober 2017)

Table 2. Phytoplankton abundance of each genus in Batuhideung waters, Pandeglang, Banten, Indonesia

\begin{tabular}{|c|c|c|c|c|c|c|}
\hline \multirow{2}{*}{ Phylum } & \multicolumn{5}{|c|}{ Station } & \multirow{2}{*}{ Total } \\
\hline & St.1 & St.2 & St.3 & St.4 & St.5 & \\
\hline Bacillariophyta & 28,490 & 5,992 & 12,035 & 3,597 & 2,620 & 52,734 \\
\hline Myzozoa & 735 & 127 & 195 & 103 & 155 & 1,315 \\
\hline Chyanophyta & - & 93 & 95 & 435 & 10 & 633 \\
\hline Euglenophyta & 200 & - & - & - & - & 200 \\
\hline
\end{tabular}


Table 3. Diversity index (H'), evenness index (E) and Simpson index (C) of phytoplankton in Batuhideung waters, Pandeglang, Banten, Indonesia

\begin{tabular}{|c|c|c|c|c|c|}
\hline & \multicolumn{5}{|c|}{ Station } \\
\hline & St.1 & St.2 & St.3 & St.4 & St.5 \\
\hline Diversity index $\left(\mathrm{H}^{\prime}\right)$ & $1.54-1.76$ & $1.30-1.83$ & $1.53-2.02$ & $1.25-1.45$ & $1.47-1.87$ \\
\hline Eveness index (E) & $0.54-0.83$ & $0.56-0.63$ & $0.52-0.84$ & $0.52-0.81$ & $0.61-0.85$ \\
\hline Simpson index (C) & $0.23-0.33$ & $0.23-0.44$ & $0.22-0.24$ & $0.30-0.38$ & $0.19-0.33$ \\
\hline
\end{tabular}

Table 4. The abundance of Zooplankton (ind/L) in Batuhideung waters, Pandeglang, Banten, Indonesia (September-October 2017)

\begin{tabular}{|c|c|c|c|c|c|c|c|}
\hline \multirow[b]{2}{*}{ Phylum } & \multirow{2}{*}{ Genus } & \multicolumn{6}{|c|}{ Station } \\
\hline & & st.1 & st.2 & st.3 & st.4 & st.5 & Total \\
\hline \multirow[t]{14}{*}{ Arthropoda } & Acartia & 97 & 87 & 175 & 39 & 43 & 441 \\
\hline & Balanus & - & 18 & 14 & 14 & 8 & 54 \\
\hline & Centropages & 22 & 22 & 34 & 80 & 128 & 286 \\
\hline & Euphasia (stadia mysis) & 4 & 2 & - & - & - & 6 \\
\hline & Larva Panaeus (Zoae stadia) & 1 & - & - & - & - & 1 \\
\hline & Microsetella & 1 & 4 & 2 & - & 4 & 11 \\
\hline & Oithona & 47 & 35 & 41 & 59 & 41 & 223 \\
\hline & Panaeus (mysis) & - & - & 2 & - & - & 2 \\
\hline & Panaeus (post-larva) & 3 & 1 & - & - & - & 4 \\
\hline & Podon & 22 & 48 & 57 & 134 & 99 & 360 \\
\hline & Portunus (Zoae Larva) & 6 & 3 & 4 & - & 2 & 15 \\
\hline & Sapphirina & 6 & 8 & 21 & 47 & 66 & 148 \\
\hline & Calanus & 20 & 17 & 24 & 5 & 13 & 79 \\
\hline & Hyperia & - & 2 & - & 2 & 2 & 6 \\
\hline \multirow[t]{5}{*}{ Mollusca } & Bivalve & 6 & - & - & - & 1 & 7 \\
\hline & Cyprinida & 5 & 2 & - & - & - & 7 \\
\hline & Larva bivalve (spat) & 1 & - & 2 & 36 & 46 & 85 \\
\hline & Limacina $s p$ & - & - & - & - & 2 & 2 \\
\hline & Atlanta & 9 & 6 & 4 & 8 & 7 & 34 \\
\hline Chaetognatha & Sagitta & 20 & 31 & 23 & 12 & 10 & 96 \\
\hline \multirow[t]{3}{*}{ Chordata } & Fritillaria fornica & - & - & 1 & - & - & 1 \\
\hline & Fritillaria & 1 & 2 & - & - & - & 3 \\
\hline & Oikopleura & 1 & 3 & 3 & 1 & 1 & 9 \\
\hline Cercozoa & Aulosphaera & 1 & 1 & - & 1 & - & 3 \\
\hline Radiozoa & Corocalyptra & - & - & - & - & 1 & 1 \\
\hline \multirow[t]{3}{*}{ Annelida } & Lapodorrhynchus & 1 & - & 1 & - & - & 2 \\
\hline & Nereis & 2 & - & - & - & - & 2 \\
\hline & Spiophanes & - & 1 & - & - & - & 1 \\
\hline \multirow[t]{2}{*}{ Ciliophora } & Protorhabdonella & 1 & - & - & - & - & 1 \\
\hline & Tintinnopsis & 1 & - & - & - & 2 & 3 \\
\hline Nematoda & Echinotheristus & 1 & - & - & - & 2 & 3 \\
\hline Cnidaria & Diphyes & - & 1 & 1 & - & - & 2 \\
\hline Protozoa & Acanthometron & - & - & - & - & 1 & 1 \\
\hline \multirow[t]{2}{*}{ Rotifera } & Notholca & - & - & - & - & 1 & 1 \\
\hline & Dromosphaera & - & - & - & 1 & - & 1 \\
\hline Total & & 279 & 294 & 409 & 439 & 480 & 1,901 \\
\hline
\end{tabular}

Table 5. Diversity index $\left(\mathrm{H}^{\prime}\right)$, evenness index (E) and Simpson index (C) of zooplankton in Batuhideung waters, Pandeglang, Banten, Indonesia (September-October 2017)

\begin{tabular}{llllll}
\hline & St. 1 & St. 2 & St. 3 & St. 4 & St. 5 \\
\hline Diversity index (H') & $1.42-1.91$ & $1.45-1.61$ & $0.97-1.70$ & $0.96-1.81$ & $1.45-1.81$ \\
Eveness index (E) & $0.66-0.83$ & $0.70-0.74$ & $0.54-0.77$ & $0.76-0.87$ & $0.75-.0 .81$ \\
Simpson index (C) & $0.19-0.36$ & $0.27-0.33$ & $0.26-0.54$ & $0.20-0.43$ & $0.22-0.29$ \\
\hline
\end{tabular}


Table 6. Values for Pearson correlation coefficients between water quality parameters and the abundance of phytoplankton and of zooplankton, across five observation sites observed in Batuhideung waters, Pandeglang, during September-October 2017

\begin{tabular}{lcccccccc}
\hline & Temperature & Clarity & Sea current & Salinity & DO & pH & Nitrate & Phosphate \\
\hline Phytoplankton & & & & & & & & \\
Pearson correlation & -0.604 & -0.053 & 0.793 & -0.056 & -0.061 & -0.144 & -0.411 & 0.122 \\
P-Value & 0.017 & 0.852 & 0 & 0.844 & 0.829 & 0.608 & 0.128 & 0.664 \\
& & & & & & & & \\
Zooplankton & & & & & & & \\
Pearson correlation & -0.18 & -0.232 & -0.051 & 0.276 & 0.11 & -0.602 & 0.259 & 0.244 \\
P-Value & 0.52 & 0.405 & 0.857 & 0.32 & 0.696 & 0.018 & 0.352 & 0.381 \\
\hline
\end{tabular}

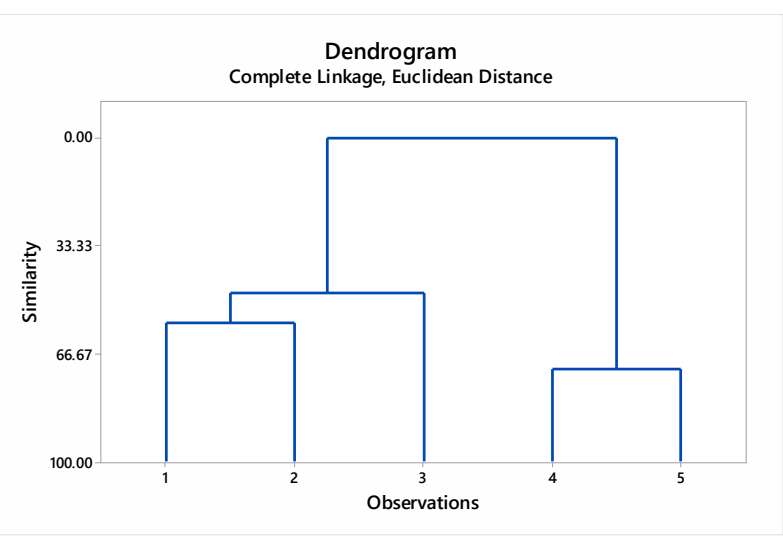

Figure 11. Dendrogram of the five observation stations based on multivariate cluster analysis of their water quality parameters.

\section{Plankton community structure}

Relationship between water quality and the phytoplankton community

Table 6 presents results for the correlation analysis between water quality parameters and the phytoplankton abundance across the five sites. Sea current had a highly significant positive significant correlation $(0.793$, p-value $<0.01$ ) with abundance of phytoplankton. Phytoplankton swimming ability is very limited so their dispersion through the seas is always highly determined by ocean currents (McManus and Woodson 2012).

Water temperature displayed a significant negative correlation $(-0.604$, p-value $<0.05)$ with phytoplankton abundance which similar to Kadim et al. (2018) and Sahu et al. (2012). Sea surface temperatures are known to affect the solubility of gases needed for photosynthesis and metabolism such as $\mathrm{CO}_{2}$ and $\mathrm{O}_{2}$. These gases are more easily dissolved at low temperatures rather than high temperatures. Consequently, the speed of photosynthesis is enhanced by low temperatures (Neori and Holm-Hansen 1982).

In contrast, abundance of the phytoplankton community in the Batuhideung waters was not significantly correlated with phosphate which contrasts to $\mathrm{Lv}$ et al (2011) concentration even though phosphate is known to promote photosynthesis, growth and development of phytoplankton. (Nybakken 1992). Similarly, phytoplankton abundance was not significantly correlated with water clarity, salinity and dissolved oxygen. Water clarity is a factor in the amount of light that is available to photosynthetic organisms at depth below the sea. The intensity of light at depth will decrease if the clarity is poor, and this is a factor influencing photosynthesis (Nybakken 1992), however, in our study, phytoplankton abundance in the Batuhideung waters showed no significant relationship to water clarity. Similarly, variation in salinity can affect the life of various types of plankton in water, but was found not to be significantly correlated with phytoplankton abundance in our study. In low-margin coastal waters where salinity is lower, the abundance of plankton community is often higher than in waters far from highmargin beaches where the salinity much higher (Simanjuntak et al. 2009).

\section{Relationship between water quality and the zooplankton community}

Based on data presented in Table $6, \mathrm{pH}$ was the only water quality parameter that was significantly correlated with zooplankton abundance which similar to Novia et al. (2016). The correlation was negative (-0.602 p-value $<0.05)$. It might be expected that the concentration of nitrate and phosphate would lead to increased zooplankton abundance (González et al. 2011), but the relationship between concentrations of these nutrients with zooplankton abundance in our study was weak and not statistically significant.

Similarly, higher DO and salinity values might be expected to boost zooplankton abundance, but in our study the correlations were insignificant and close to zero. In some other studies, a positive correlation has been found between salinity and zooplankton abundance (Chua 1970).

\section{REFERENCES}

Abdul WO, Adekoyaq EO, Ademolu KO, Omoniyi IT, Odulate DO, Akindokun TE, Olajide AE. The effects of environmental parameters on zooplankton assemblages in tropical coastal estuary, South-west, Nigeria. Egypt J Aquat Res 42: 281-287.

Amri K, Priatna A, Suprapto. 2014. Oceanographical characteristic and phytoplankton abundance in Sunda Strait waters in the East Monsoon. Bawal 6 (1): 11-20.

APHA (American and Public HealthAssociationn). 1979. Standard Methods For The Examination of Water and Wastewater. 17th d. APHA, AWWA (American Waste WaterAssociationn) and WPCF (Water Pollution Control Federation). Poet City Press.Baltimoree. Maryland. 
Basu S, Mackey KRM. 2018. Phytoplankton as key mediators of the biological carbon pump: their responses to a changing climate. Sustainability 10. DOI: 10.3390/su10030869

Bharathi MD, Sarma VVSS, Ramaneswari K, Venkataramana V. 2018. Influence of river discharge on abundance and composition of phytoplankton in the western coastal Bay of Bengal during peak discharge period. Mar Poll Bull 133: 671-683.

Brierley AS. 2017. Plankton. Curr Biol 27 (11): R478-483.

Chua TE. 1970. A preliminary study on the plankton of the Ponggol estuary. Hydrobiologia 35: 252-272.

Cira EK, Paerl HW, Wetz MS. 2016. Effects of nitrogen availability and form on phytoplankton growth in a eutrophied estuary (Neuse River Estuary, NC, USA). PloS One 11 (8): e0160663. DOI: 10.1371/journal.pone.0160663

Cui L, Lu X, Dong Y, Cen J, Cao R, Pan L, Lu S, Ou L. 2018. Relationship between phytoplankton community succession and environmental parameters in Qinhuangdao coastal areas, China: A region with recurrent brown tide outbreaks. Ecotoxicol Environ Saf 159: 85-93.

Fauziyah, Priatna A, Prakoso WF, Hidayat T, Surbakti H, Nurjuliasti E. 2018. Measurement and analysis of acoustic backscattering strength for characteristics of seafloor sediment in Indian Ocean WPP 572573. IOP Conf Ser Earth Environ Sci. 162 012024. DOI: $10.1088 / 1755-1315 / 162 / 1 / 012024$

González EJ, Matos ML, Peñaherrera C, Merayo S. 2011. Zooplankton abundance, biomass and trophic state in some Venezuelan reservoirs. Biomass and Remote Sensing of Biomass. InTech, Rijeka, Croat. DOI: $10.5772 / 16491$

Giesecke R, Vallejos T, Sanchez M, Teiguiel K. 2017. Plankton dynamics and zooplankton carcasses in a mid-latitude estuary and their contributions to the local particulate organic carbon pool. Continent Shelf Res 132: 58-68.

Hays GC. 2017. Ocean currents and marine life. Curr Biol 27 (11): R470R473.

Hemraj DA, Hossain MdA, Ye Q, Qin JG, Leterme SC. 2017. Plankton bioindicators of environmental conditions in coastal lagoons. Estuar Coast Shelf Sci 184: 102-114

Isnansetyo A, Kurniastuty. 1995. Teknik Kultur Phytoplankton dan Zooplankton. Kanisius, Yogyakarta. [Indonesian]

Kadim MK, Pasisingi N, Kasim F. 2018. Spatial and temporal distribution of phytoplankton in the Gorontalo Bay, Indonesia. AACL Bioflux 11 (3): 833-845.

Kasma E, Osawa T, Sandi Adnyana IW. 2007. Estimation of primary productivity for tuna in Indian Ocean. Ecotrophioc J Environ Sci 4 : $86-91$

Ke Z, Tan Y, Ma Y, Huang L, Wang S. 2014. Effects of surface current patterns on spatial variations of phytoplankton community and environmental factors in Sunda shelf. Continent Shelf Res 82: 119 127.

Krebs C J. 1999. Ecological Methodology. 2nd ed. University of British Columbia, Vancouver.

Lin S, Litaker RW, Sunda WG. 2016. Phosphorus physiological ecology and molecular mechanisms in marine phytoplankton. J Phycol 52 (1): 10-36.

Longhurst AR, Pauly D. 1987. Ecology of Tropical Oceans. Academic Press Inc., California.
Lv J, Wu H, Chen M. 2011. Effects of nitrogen and phosphorus on phytoplankton composition and biomass in 15 subtropical, urban shallow lakes in Wuhan, China. Limnologica 41: 48-56.

Madhu NV, Martin GD, Haridevi CK, Nair M, Balachandran KK, Ullas N. 2017. Differential environmental responses of tropical phytoplankton community in the southwest coast of India. Reg Stud Mar Sci 16: 21-35.

McConnaughey BH, Zottoli R. 1983. Introduction to Marine Biology. 4th ed. The C.V. Mosby Company, London.

McManus MA, Woodson CB. 2012. Plankton distribution and dispersal (Review). J Exp Biol 215: 1008-1016.

Neori A, Holm-Hansen O. 1982. Effect of temperature on rate of photosynthesis in Antarctic phytoplankton. Polar Biol 1: 33-38.

Nybakken JW. 1992. Marine Biology: An Ecological Approach. Gramedia, Jakarta.

Odum EP. 1971. Fundamentals of Ecology. 3rd ed. W.B. Saunders Company, Philadelphia.

Pratiwi NTM, Ardhito, Wulandari DY, Iswantari A. 2016. Horizontal distribution of zooplankton in Tangerang coastal waters, Indonesia. Procedia Environ Sci 33: 470-477.

Renaud SM, Thinh L-V, Lambrinidis G, Parry DL. 2002. Effect of temperature on growth, chemical composition and fatty acid composition of tropical Australian microalgae grown in batch cultures. Aquaculture 211: 195-214.

Sahu G, Satpathy KK, Mohanty AK, Sarkar SK. 2012. Tropical marine phytoplankton assemblages and water quality characteristics associated with thermal discharge from a coastal power station. Indian J Geo-Mar Sci 41 (3): 223-241.

Simanjuntak M. 2009. The correlation of environment factor chemistry, physics on plankton distribution in the East Belitung Waters, Bangka Belitung. Jurnal Perikanan 11 (1): 31-45. [Indonesian]

Simon N, Cras A-L, Foulon E, Lemée R. 2009. Diversity and evolution of marine phytoplankton. C. R. Biologies 332: 159-170.

Sutiana A, Takarina ND, Nurhudah M. 2018. Gonad maturity level of mackerel from fishing ground of Pandeglang area. AIP Conference Proceedings 2023: 020132. DOI: 10.1063/1.5064129.

Tan KS, Ransangan J. 2017. Effects of nutrients and zooplankton on the phytoplankton community structure in Marudu Bay. Estuar Coast Shelf Sci 194: 16-29.

Vajravelu M, Martin Y, Ayyappan S, Mayakrishnan M. 2018. Seasonal influence physicochemicalcal parameters on phytoplankton diversity, community structure and abundance at Parangipettai coastal waters, Bay of Bengal, South East Coast of India. Oceanologia 60 (2): 114 127

Vollenweider R. et al. 1997. Characterization of The Trophic Condition of Marine Coastal Waters With Special Reference to the NW Adriatic Sea: Proposal for a Trophic Scale, Turbidity, and Generalized Water Quality Index. John Willey \& Sons Ltd., Canada.

Xu T, Li S, Hamzah F, Setiawan A, Susanto RD, Cao G, Wei Z. 2018. Intraseasonal flow and its impact on the chlorophyll-a concentration in the Sunda Strait and its vicinity. Deep Sea Research Part I: Oceanographic Research Papers 136: 84-90.

Yang G, Li C, Wang Y, Wang X, Dai L, Tao Z, Ji P. 2017. Spatial variation of the zooplankton community in the western tropical Pacific Ocean during the summer of 2014. Continent Shelf Res 135: 14-22.

Yao C-L, Somero GN. 2014. The impact of ocean warming on marine organisms. Chinese Sci Bull 59 (5-6): 468-479. 